\title{
Adaptation and validation questionnaire for measuring the perceived quality by users external customer of the golf courses: Andalusia (Spain)
}

\author{
Adaptación y validación de un cuestionario para medir la percepción de la calidad \\ percibida por los usuarios externos de los campos de golf: Andalucía (España)
}

\author{
Marta García-Tascón ${ }^{1}$, Marcos Pradas-García ${ }^{1}$, Lucía Abenza-Cano ${ }^{2}$, \\ Elena Conde-Pascual ${ }^{3}$, Ana $\mathbf{M}^{\mathbf{a}}$ Gallardo-Guerrero $^{3}$ \\ 1 Facultad Ciencias del Deporte. Universidad Pablo de Olavide, Sevilla. España. \\ 2 ARETÉ Research Group. Facultad Deporte. Universidad Católica de Murcia. España. \\ 3 GDOT Research Group. Facultad Deporte. Universidad Católica de Murcia. España.
}

CORRESPONDENCIA:

Marta García Tascón

margata@upo.es

Recepción: julio 2020 • Aceptación: enero 2021
CÓMO CITAR EL ARTÍCULO:

García-Tascón, M., Pradas, M., Abenza-Cano, L., Conde-Pascual, E., Gallardo, A. M, (2021). Adaptation and validation questionnaire for measuring the perceived quality by users external customer of the golf courses: Andalusia (Spain). Cultura, Ciencia y Deporte, 16(49), 379-392. http://dx.doi.org/10.12800/ccd.v16i49.1500

\section{Abstract}

The objective of this work is to translate, adapt and validate the Customer Service Survey Quality Golf Course (CSQSGC). This tool is the most complete in the literature, and it is the best questionnaire to assess the perceived quality of the users. of the golf courses of Andalusia (Spain). In addition, its psychometric properties are examined: reliability and concurrent validity. There was a professional translation into Spanish of each item, content adaptation, evaluation of compression of the instrument through pilot testing, analysis of reliability with Cronbach's alpha coefficient and validity, with an exploratory factor analysis, a confirmatory factor analysis of the instrument. Eleven expert judges participated in the process of adaptation and validation. Test-retest reliability methods were applied to a sample of 50 participants with an interval over a week. Subsequently, the questionnaire is applied to 200 users of golf courses. The adapted and validated instrument Analysis of Perceived Quality of the Game of Golf (CAPG) may be used to evaluate the quality of the golf courses based on the feedback of the users. It has a structure of 39 items (four more items added from the original version) divided into four subscales, matching with the original version, and it shows positive results for reliability and validity in the Spanish version. It is a useful tool for managers, because it allows the detection of deficiencies and areas for improvement for golf courses.

Key words: Validation, questionnaire, perceived quality, users; golf, sports management.

\section{Resumen}

El objetivo de este trabajo es traducir, adaptar y validar el cuestionario "Customer service quality survey golf course" (CSQSGC). Esta herramienta es la más completa en la literatura y es el mejor cuestionario para evaluar el grado de calidad percibida de los usuarios de los campos de golf de Andalucía (España). Se realizó una traducción profesional al español de cada ítem, adaptación de contenido, evaluación de compresión del instrumento mediante prueba piloto, análisis de confiabilidad con coeficiente alfa de Cronbach y validez, con análisis factorial exploratorio, análisis factorial confirmatorio del instrumento. Once jueces expertos participaron en el proceso de adaptación y validación. Se aplicaron métodos de confiabilidad test-retest a una muestra de 50 participantes con un intervalo de más de una semana. Posteriormente, se aplica el cuestionario a 200 usuarios de campos de golf. El instrumento adaptado y validado: Análisis de "Calidad percibida en el juego del golf" (CAPG) puede ser usado para evaluar la calidad de los campos de golf en función de la opinión de los usuarios. Tiene una estructura de 39 ítems (cuatro ítems más agregados de la versión original) divididos en 4 subescalas, coincidentes con la versión original, y muestra resultados favorables de fiabilidad y validez en su versión en español. Es una herramienta útil para los gestores, pues permite detectar deficiencias y las áreas de mejora de los campos de golf.

Palabras clave: Validación, cuestionario, calidad percibida, golf, usuarios, gestión deportiva. 


\section{Introduction}

Golf has become a multifaceted industry (Barciela, 2017). González \& Suárez (2011) point out that in the world there are about 80 million players, North America (mainly the United States) with almost 50\% and Asia (mainly Japan) with $20 \%$, are the areas that provide the highest volumes of players. In this regard, according to the European Golf Association (EGA), Europe has more than 4 million golfers and Spain 271,170 golf licenses according to the Royal Spanish Golf Federation (RFEG, 2019).

The consultant Aguirre Newman, in a study conducted in 2011, said a million golf tourists visit Spain every year, being the second most popular country for golf tourists after the United States, a sector that generates 2 billion euros also help other industries (Barciela, 2017). Linking the golf industry in Spain with the tourism sector is evident in $41 \%$ of the rounds played in Spanish courses are by foreign players (Aymerich \& Anabitarte, 2016). For 29\% of European golf tourists, Spain is the favourite destination, with the British being the most numerous (KPMG, 2016). Grimaldi et al. (2018) find that the total assets and operating income of organizations of Spanish golf have not been affected by the economic crisis, nor by the rise of VAT to $13 \%$, contrary to the statement by Benitez (2013) that indicated that the rise would have harmful consequences for the sector.

In Spain, golf courses are scattered throughout the country, although they are mainly concentrated on the Mediterranean coast and the Costa del Sol. There are 446 golf courses in Spain at present (RFAG, 2020a), of which 106 are in Andalusia, 23,76\% in Costa del sol (RFAG, 2020b). In Andalusia, golf generates about 700 million euros per year and shows steady growth. Andalusia is positioned as a golf destination among US operators (Diario de Sevilla, 2015). The Costa del Sol is investing in golf: major golf tournaments, Andalucía Costa del Sol's Spain Women's Open and the Andalucía Valderrama Masters Estrella Damm, by attracting big sponsors and audiences, is generating direct and indirect income in the area, and visibillize their golf courses, Finca Cortesin best golf resort in Europe 2017 and Valderrama Golf Club Best valued at 2017 (Visitacostadelsol, 2018).

One of the fundamental objectives for the management area is the continuous improvement of quality, resulting in improved customer service, business optimization, of the events, and the consequent improvement in competitiveness (Lambrect et al., 2009). According Pincay-Quimiz \& Romero-Maquilón (2015), it is essential for the implementation of an internal control system to optimize the use of human, material and financial resources and, also to create an appropriate structure to ensure compliance with the objectives of the organization (García-Tascón, 2009; Ko et al., 2010; Theodorakis et al., 2013; Vacher et al., 2017) or even, also in virtual games, because the perceived quality is a multidimensional and hierarchical construct.

In the literature, there are many studies between the concepts of perceived quality, perceived value, satisfaction, expectations, and customer (Parasuraman et al., 1985, 1988; Zeithaml et al., 1996). Quality perception is formed through an individual's opinion of a service derived from comparing consumption expectations and perceptions of the real performance of the service (Magaz-González et al., 2020), comparing the evaluation of the service delivery and the outcome (Calabuig-Moreno et al., 2010; Cronin et al., 2000; Hightower et al., 2002).

Different models of quality management emphasize the importance of incorporating the opinions and perceptions of the user into the conceptualization and measurement of quality of service, to the point that it now makes no sense to talk about total quality if one does not also take into account the quality perceived by the customer (Chelladurai \& Chang, 2000; Serrano et al., 2010; Tsitskari et al., 2006), because participants may perceive quality differently than spectators (Shonk \& Chelladurai, 2008). The structure of these models is affected by the characteristics of each sporting or service, adding specific dimensions to the particular context such as SPORTSERV (Theodorakis et al., 2001). The SERVQUAL instrument (Parasuraman et al., 1985), uses five dimensions (tangibles, reliability, responsiveness, assurance, empathy). Others authors use dimensions and sub-dimensions (Brady \& Cronin, 2001; Clemes et al., 2011) to evaluate the quality.

There is a direct and positive relationship between global quality and perceived value (Alonso-Dos-Santos \& Pérez-Campos, 2015; Calabuig-Moreno et al., 2015; Magaz-González et al., 2020; Montesinos-Saura et al., 2018; Shonk \& Chelladurai, 2008; Theodorakis et al., 2015; Zeithaml et al., 1996). And there is controversy surrounding between perceived value and satisfaction (direct and an inverse or non-existent). The majority defend that the perceived value affects satisfaction (Brady et al., 2005; Crespo-Hervás et al., 2019; Hightower et al., 2002; McDougall \& Levesque, 2000; Murray \& Howat, 2002). Martínez-García \& Martínez-Caro (2010) emphasize that clients can form perceptions of service quality at different levels, such as overall service quality or with different quality sub-dimensions. On the other hand, there are multiple 
studies that point to satisfaction and perceived value as antecedents of future intentions, and, therefore, indirectly to global quality, as a precursor to these (Brady et al., 2005; McDougall \& Levesque, 2000; Murray \& Howat, 2002; Zeithaml et al., 1996).

Also, the expectations influence satisfaction and perceived quality (Magaz-González et al., 2020). Martínez-García \& Martínez-Caro (2010) emphasize that clients can form perceptions of service quality at different levels of abstraction, from the most aggregated (such as overall service quality) to the most disaggregated, with different quality sub-dimensions and they proposing the inclusion of a measure of overall service quality. Clemes et al. (2011) reflect that the perceptions of different main dimensions form a global perception of the quality of the service and these, in turn, influence the perceived value and satisfaction of a service. Zeithaml et al. (1996) argue that behavioral intentions diagnose actual behaviors better than quality and satisfaction. Pérez-Campos (2010) introduces the evaluation of global service quality in their questionnaires.

There is another concept of quality of management since the Spanish Association for Standardization and Certification (AENOR, 2008) establishes the quality standard UNE 188001: 2008 Golf Courses, requirements for the service (are a set of standards, experimental standards and reports (standards) created in the Technical Committee for Standardization (CTN), a pioneer in its field) which encompasses the specific requirements for golf courses, and that define the level of customer service (AENOR, 2011). The UNE standard with a final version in 2011 establishes the requirements for the service of golf courses. Decree 309/2010, of June in Andalusia, regulates the conditions of implementation and operation of golf courses and to measure the quality of golf courses in Andalusia promotes the Scale for Assessing the Perceived Quality of Golf Clubs, QGOLF-9 designed and validated by Serrano-Gómez et al. (2013), which consists of 15 main evaluation elements, but does not include essential aspects such as access, state of the course, ancillary services such as car parks, etc.

Therefore, the Spanish government of tourism section has a specific standard quality tourism by the Institute for Spanish Tourism Quality (ICTE). Obtaining the "Q" mark is a sign of an improvement of the quality of management and services in all facilities, e.g. the course of the Spanish Golf Federation (ICTE, 2011). In addition, in relation to golf and tourism, some courses install the new RMS system (Revenue Management System) to control the management of their fields (Díaz et al., 2013).
The most complete tool available today, provided by Crilley et al. (2002) of the CERM PI research group created by the University of Australia, measures the perceived quality of public courses in Australia and also, takes into account these aspects. With corresponding adjustments, it may be applied to golf courses in Spain and particularly in Andalusia. This tool evaluates 41 indicators that cover financial and non-financial areas of operational management (OM), plus 21 attributes of quality customer service (CSQ) to identify areas for improvement in the management of golf courses from the point of view of external customers (Crilley et al., 1997; Crilley et al., 1999; Murray \& Howat, 2002).

For these reasons, the main objective of this study is the adaptation of Crilley et al. (2002) instrument for measurement of perceived quality of clients of the golf courses in Andalusia, Spain.

\section{Method}

In the process of adaptation and validation of the original questionnaire, Crilley et al. (2002) have followed the criteria proposed by Daouk et al. (2006), Hambleton (2005), and Venerandi (2012), who argue that adapting an instrument to a new language and a new culture should provide guarantees of conceptual, linguistic and metric equivalence. A key task includes professional translation into Spanish of each item, content adaptation by an expert, evaluation of compression of the instrument through pilot testing, analysis of reliability and validity of the instrument adapted.

1. Translation of the original version of the Crilley et al. (2002) questionnaire

To guarantee conceptual, linguistic and metric equivalence a translation process and retro-translation was undertaken. In the translation of the questionnaire from English to Spanish, two linguistic experts participated in the area of professional translation.

\section{Grammatical, linguistic, and semantic evaluation. Readability analysis}

An inverse translation has also been performed: methodological condition required to verify that the original version is unchanged from the translated version. The translation was done by a certified expert translator who did not know the original document. Finally, relevant comparisons were made. The translated version presented no differences from the original questionnaire. 
Table 1. Participating experts.

\begin{tabular}{|c|c|c|c|}
\hline Experts & Profession & Sex & Experience \\
\hline Group 1 & Graduates in Sports Science & 2 males and 1 female & $\begin{array}{l}\text { 1. } 12 \text { years } \\
\text { 2. } 8 \text { years } \\
\text { 3. } 10 \text { years }\end{array}$ \\
\hline Group 2 & Agronomists & 2 males and 1 female & $\begin{array}{l}\text { 1. } 21 \text { years } \\
\text { 2. } 16 \text { years } \\
\text { 3. } 14 \text { years }\end{array}$ \\
\hline Group 3 & Sports managers & 2 males and 1 female & $\begin{array}{l}\text { 1. } 10 \text { years } \\
\text { 2. } 6 \text { years } \\
\text { 3. } 17 \text { years }\end{array}$ \\
\hline Group 4 & Managers of golf facilities & 2 males & $\begin{array}{l}\text { 1. } 22 \text { years } \\
\text { 2. } 12 \text { years }\end{array}$ \\
\hline
\end{tabular}

\section{Expert study}

Cabero \& Llorente (2013) claim that evaluation by expert opinion is the validation method increasingly used in research. Experts can intervene effectively in validating an instrument undergoing standardization procedures and translation to suit different cultural contexts. They can also assess the content validity of the items for optimum readability levels, compliance and adequacy of the statements of the text (Pérez, 2001). It is basically an evaluation strategy that presents the possibility of obtaining a wide and detailed information on the subject matter and the quality of the responses from the judges (Perez et al., 1998). Expert judgment is also a useful method for verifying the reliability of an investigation (EscobarPérez \& Cuervo-Martínez, 2008).

To develop the process of adaptation and validation of the translated instrument, 11 experts' judges were selected from four different professional groups linked to sport management activities and the operation of golf courses following the instructions of different researchers (Berk, 1990; Calabuig-Moreno \& Crespo, 2009; Calabuig-Moreno et al., 2010; Carretero-Dios \& Pérez, 2005; Dunn et al., 1999; Thomas \& Nelson, 2007; Wiersma, 2001), (Table 1).

To facilitate the work of the experts, an evaluation instrument was designed, where the adequacy and relevance-suitability of each of the indicators were evaluated through the Likert scale of 5 points ( $1=$ strongly disagree; 5 = strongly agree) and evaluate the questionnaire items based on a 5-points Likert scale based on suitability and relevance ( $1=$ not relevant; 5 = entirely appropriate). In addition, it was included a blank space to write down the observations corresponding to each item.

This validation process depended on where the experts were and their availability. Communications were established mainly by phone, e-mail or Skype. And finally, the experts had an adequacy in the drafting of the items, adaptation and linguistic correction of the items, clarity in the writing of the items, organization of the items, presentation and design of the items and instrument.

The instrument validation process was carried out in a personalized way with each of the experts (Berk, 1990). Each expert was consulted as to her/ his opinion on the inclusion of two new questions: about the level of updating of the club's website and if the facilities had facilities for people with reduced mobility. Everyone agreed. In addition, they were asked their impressions of what other aspects were missing or if any of the items should be removed to improve the questionnaire. They suggested adding two other questions: about the state of the greens and if the club had a social area.

Four items to update the original instrument were added (Alonso-Serrano \& Segado-Segado, 2015; Gálvez-Ruiz \& Morales-Sánchez, 2015; Zarco-Pérez, et al., 2012).

1. The club is accessible for the disabled

2. The club's website provides information on all the services provided.

3. The club has a social area.

4. The state of the greens is perfect.

Table 2 shows some observations that the experts made generically, on those essential aspects that, according to their criteria, should remain in the final instrument.

The expert group analysed the adequacy and relevance of the proposed variables to measure the perceived quality of the golf course among external users. Regarding the degree of "matching" of the items, $95 \%$ of the judges gave a response of $4-5$ on the Likert scale. Everyone agreed to keep the items in the original questionnaire and add the items raised by researchers and some experts. As the scale of "relevance-suitability" $90 \%$ of the judges gave an answer of 4-5 on the 1-5 scale used. 
Table 2. Relevant comments from experts.

\begin{tabular}{lll}
\hline Experts & Profession & General Comments \\
\hline Group 1 & Graduates in Sports Science & Human Factor (personal) and regulations \\
Group 2 & Agronomists & State of the greens and neglected areas \\
Group 3 & Sports managers & Golf course website and etiquette rules \\
Group 4 & Managers of golf facilities & Accessibility, mobility, website \\
\hline
\end{tabular}

Once the evaluation of the experts was completed, their contributions were considered to make the appropriate modifications, since their suggestions guarantee a concordance between the methodological design of the instrument that is validated and the construct under study. The adapted instrument was subjected to the corresponding reliability and validity tests.

\section{Analysis of reliability and validity of the instrument. Pilot study. Test-Retest}

To verify the validity of the construct, the instrument was applied through a one-week test-retest to a sample of 50 external clients (including 10 golf experts). Validity and reliability are the two quality criteria to be met by all measuring instruments after undergoing expert consultation in order that researchers can use them in their studies (Arribas, 2004).

The reliability of the instrument determines stability of understanding of the items by individuals. In this investigation the test-retest method is used, to determine the degree to which each person truly scores the same at two different times, preventing the person filling out the questionnaire by chance; and eliminating potential bias on the level of skill that the subject must have to complete the questionnaire (Baumgartner, 2000; Conroy \& Metzler, 2003; Trigueros et al., 2020, Zhu et al., 1998).

Inclusion criteria were: being over 18 , being a user of a golf course, and having a handicap (license granted by the RFEG to allow the player to go out to play the field and measure their level of play). Selected users were informed about the characteristics of the test-retest evidence and of its importance to validate the tool under study, and that they should re-engage the next week to fill out the questionnaire again. They gave their consent to participate in this process, which was voluntary, confidential and anonymous.

The implementation of the pilot had the following objectives:

1. To test the validity of the pilot questionnaire.

2. To check if the user to whom the questionnaire is intended correctly understands the different items raised in formal terms.
3. To test whether the questionnaire can be completed within a reasonable time.

4. To see if it is possible to close some of the open questions from the response options given by the users.

5. To check if the questionnaire is of interest to the user.

6. To analyze whether the formulated items meet the objectives for which they are designed.

During the application of the questionnaires to the sample of 50 selected clients, their impressions were observed. In addition, to debug the instrument, the questions or doubts that the surveyed users might have when answering the questionnaire were noted. At the end, they were also asked for an overall assessment and if there were terms that could be confusing. Subsequently, the following week a second application was made to know the consistency in the responses. There were no significant changes, and the responses were stable over time. Cronbach's alpha coefficients associated to both data bases were calculated taking into consideration 52 elements (Variables 1.1-1.8, A1-A22, B1-B22): .888 (test) and .885 (retest), which demonstrate internal consistency of scales and the reliability of the instrument. The information provided was very useful for designing the final questionnaire, with items drawn in the most explicit way possible (Morrow et al., 2010).

\section{Definitive instrument}

Using the same inclusion criteria, the sample was expanded to 200 members of seven Andalusian Golf clubs. It is a probabilistic (non-intentional) study (the census is known but not accessible) and at least there was 28-29 participants from each golf club. This sample size is recommended according to some studies (Alaminos \& Castejón, 2006; Calabuig-Moreno \& Crespo, 2009; Carretero-Dios \& Pérez, 2005; Kim \& Walker, 2012; Martín, 2004; Morales et al., 2003; Thomas \& Nelson, 2007). The sample consisted of 131 men $(65.5 \%)$ and 69 women (34.5\%) aged between 18 and 80 years (Table 3 ). $40 \%$ of participating users were aged between 45 and 60 years, $61 \%$ were born 
Table 3. Characteristics of users in the sample.

\begin{tabular}{|c|c|c|c|}
\hline Variables & \multicolumn{2}{|l|}{$\mathbf{N}$} & Percentage \\
\hline Gender & \multicolumn{2}{|l|}{200} & $100 \%$ \\
\hline Male & \multicolumn{2}{|l|}{131} & $65.5 \%$ \\
\hline Female & \multicolumn{2}{|l|}{69} & $34.5 \%$ \\
\hline \multicolumn{4}{|l|}{ Age } \\
\hline $18-30$ & \multicolumn{2}{|l|}{37} & $18.5 \%$ \\
\hline $30-45$ & \multicolumn{2}{|l|}{ 3. 4} & $17 \%$ \\
\hline $45-60$ & \multicolumn{2}{|l|}{80} & $40 \%$ \\
\hline $60-80$ & \multicolumn{2}{|l|}{49} & $24.5 \%$ \\
\hline \multirow[t]{2}{*}{ Country of birth } & Spain & 122 & $61 \%$ \\
\hline & Other countries & 78 & $39 \%$ \\
\hline \multirow[t]{2}{*}{ Residence } & Spain & 147 & $73.5 \%$ \\
\hline & Other countries & 53 & $26.5 \%$ \\
\hline \multicolumn{4}{|l|}{ Handicap } \\
\hline $1-10$ & \multicolumn{2}{|l|}{47} & $23.5 \%$ \\
\hline $10-20$ & \multicolumn{2}{|l|}{51} & $25.5 \%$ \\
\hline $20-36$ & \multicolumn{2}{|l|}{102} & $51 \%$ \\
\hline
\end{tabular}

in Spain. 73.5\% reside in Spain. Players of different nationalities were also present, mainly from Sweden, Denmark, Norway, the United Kingdom, and the United States, with varying handicaps, 102 of them (51\%) with 20-36 handicap. 60\% practice golf for leisure, $33.5 \%$ are club members, $46 \%$ live more than $46 \mathrm{~km}$ of the course, $40 \%$ of them are occasional customers, $52 \%$ spend four-five hours on golf per day, $30 \%$ have more than five years' experience.

The questionnaire was applied to the selected users and a database was built in Microsoft Excel to facilitate the organization and review of the information obtained. Subsequently, a database was prepared using the statistical program IBM SPSS, Version 24 for processing, which included a descriptive analysis, exploratory factor analysis, confirmatory factor analysis and reliability analysis of the scales.

\section{Results and Discussion}

From the information obtained in conducting the questionnaire with 200 external clients, exploratory factor analysis (EFA) was performed using SPSS 24, to determine the presence of factors or groups of variables correlated with each other (factor structure). In the exploratory factor analysis (EFA) 1.1-1.8 variables related to the use of field, characteristics of external clients (age, gender, handicap), variables A1-A22 (expectations) and B1-B22 (operation) were included.

\section{Exploratory factor analysis}

It used the maximum likelihood method for extracting factors and Varimax method for generating the rotated component matrix. It was possible to obtain

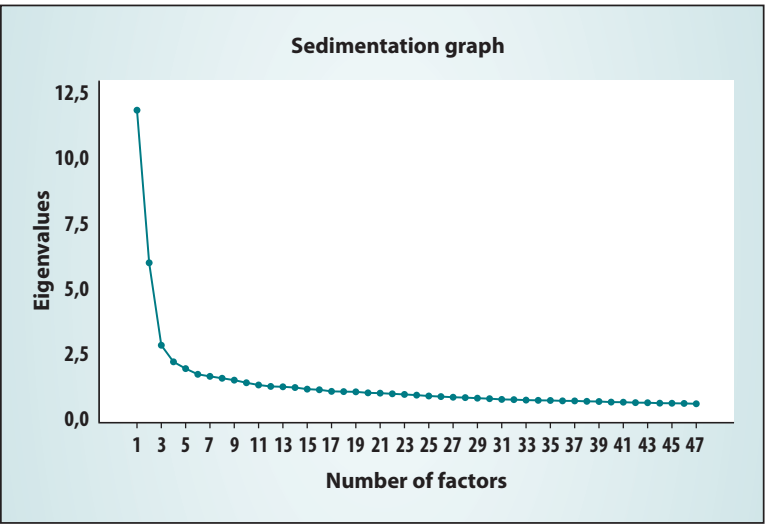

Figure 1. Scree plot. EFA.

convergence with five iterations. A valid measure of sampling adequacy Kaiser-Meyer-Olkin (KMO) of .898 was obtained (Hair et al., 2006). The Bartlett sphericity test $\left(\chi^{2}=2635.451, \mathrm{df}=231\right.$, Sig. $\left.=.000\right)$ indicates that the correlation matrix is significantly different from the identity matrix, the variables are significantly correlated and therefore an exploratory factor analysis should be performed (0) (Aaker \& Day, 1989; Alaminos \& Castejón, 2006; Babbie, 2000; Morales et al., 2003; Thomas \& Nelson, 2007).

Attending to the scree plot obtained (Figure 1) four factors were extracted explaining $66.762 \%$ of the variance of the data and that was comprised of four groups of highly correlated variables. Variables with factor loads greater than or equal to 0.4 were considered significant within each group (Balanza et al., 2008; Calabuig-Moreno et al., 2010; Nunally, 1978; Parra et al., 2014; Wiersma, 2001; Zhou \& Ap, 2009).

- Factor 1: Variables A5, A6, A9-A12, A14-A17, A19, A21, A22 (expectations), (35.657\%)

- Factor 2: Variables B14-B18 (operation) (16.186\%)

- Factor 3: Variables Age, Handicap (characteristics of external clients), $7.752 \%$

- Factor 4: Variables 1.2, 1.3, (Use the golf course), $7.167 \%$

Table 4 shows the rotated component matrix and factorial loads corresponding to variables groups in the four EFA model. Variables not included in Factor 1 show a strong Spearman's rho bivariate correlation with the other expectation variables $(p<.05)$. Variables not included in Factor 2 show a strong Spearman's rho bivariate correlation with the rest of operation variables $(p<.05)$. Pairs of variables 1.2 (Are you a partner of this golf course?) / 1.7 (how many days a week do you usually play?), and 1.3 (How far is the golf course from your home?) / 1.5 (How much time do you spend in the course?) do not show significant bivariate 
correlations ( $p>05)$. Variables Age and Gender are not statistically correlated in this sample $(p>.05)$. These items can give important information to the club.

\section{Confirmatory factor analysis}

The four-factor model obtained (EFA) was subjected to a confirmatory factor analysis (CFA) based on the data obtained during the application of the instrument to 200 external costumers.

SmartPLS 3 program was used to construct the corresponding structural model. SmartPLS is a graphical user interface for variance-based structural equation modeling (SEM) using partial least squares (PLS), for estimating path models with latent variables using the PLS-SEM algorithm, (Ringle et al., 2015).

Variables involved in the EFA model to be tested together with dependent variable relative to the perceived quality has been called Specific perceived quality of facilities (SPQF) of external clients (SPQF, evaluated in a 0-10 scale), where extracted from the SPSS data base, saved in a .cSv format file and imported into SmartPLS 3.

In order to evaluate global relationships among factors and the influence of expectations, operation variables, characteristics of external clients and use of the golf course on the dependent variable (SPQF), a number of 5000 bootstrap subsamples were analyses at a 95\% confidence interval (two-tailed, Bias-Corrected and Accelerated Bootstrap) to determine the level of significance for each coefficient path (Table 5).

PLS-SEM algorithm was applied in order to fit the CFA model. Model fit indices were extracted from SmartPLS report (Table 6). Root mean square residual (RMSR) is a measure of the mean absolute value of the covariance residuals (RMSR $=.07)$. A value less than .10 in the estimated model reflects a good fit. Normed fit index (NFI) represents an incremental fit measure. The closer to 1 , the better the fit. In this case NFI = .75 which may be considered an acceptable index, given the sample size we have, the discrete characteristics of the analysed variables due to the use of Likert-type scales. Some questionnaires have empty fields (no answers). Loads associated to variables involved in each factor are acceptable (above .7).

\section{Discriminant validity of factors}

The discriminant validity analysis allows to ensure that a reflective construct has the strongest relationships with its own indicators. Discriminant validity of the instrument is checked through the Fornell-Laecker criterion (Table 7).
Table 4. Rotated Component Matrix ${ }^{\mathrm{a}}$.

\begin{tabular}{|c|c|c|c|c|}
\hline \multirow{2}{*}{ Variables } & \multicolumn{4}{|c|}{ Component } \\
\hline & 1 & 2 & 3 & 4 \\
\hline A11 & .833 & & & \\
\hline A16 & .803 & & & \\
\hline A17 & .800 & & & \\
\hline A10 & .796 & & & \\
\hline A15 & .782 & & & \\
\hline A14 & .772 & & & \\
\hline A21 & .764 & & & \\
\hline A5 & .760 & & & \\
\hline A22 & .760 & & & \\
\hline A9 & .758 & & & \\
\hline A12 & .732 & & & \\
\hline A8 & .723 & & & \\
\hline A19 & .714 & & & \\
\hline B17 & & .837 & & \\
\hline B15 & & .831 & & \\
\hline B16 & & .826 & & \\
\hline B18 & & .781 & & \\
\hline B14 & & .757 & & \\
\hline Handicap & & & .854 & \\
\hline Age & & & .831 & \\
\hline 1.3 & & & & .828 \\
\hline 1.2 & & & & .781 \\
\hline
\end{tabular}

Extraction Method: Principal Component Analysis.

Rotation Method: Varimax with Kaiser Normalization.

Table 5. Coefficients path estimation and evaluation. SmartPSL / Bootstrap method.

\begin{tabular}{lccccc}
\hline & $\begin{array}{c}\text { Original } \\
\text { Data }\end{array}$ & $\begin{array}{c}\text { Sample } \\
\text { mean }\end{array}$ & St.Dev. & $\mathbf{t}$ & Sig. \\
\hline F1 -> F2 & .360 & .370 & .054 & 6.697 & .000 \\
F2 -> SPQF & .330 & .332 & .083 & 3.987 & .000 \\
F3 -> F1 & -.161 & -.166 & .068 & 2.362 & .018 \\
F3 -> SPQF & -.236 & -.234 & .058 & 4.091 & .000 \\
F4 -> F3 & -.351 & -.352 & .060 & 5.900 & .000 \\
F4 -> SPQF & .326 & .325 & .071 & 4.604 & .000 \\
\hline
\end{tabular}

Table 6. Model fit indices.

\begin{tabular}{lcc}
\hline & Saturated model & Estimated model \\
\hline SRMR & .066 & .070 \\
d_ULS & 1.206 & 1.340 \\
d_G & .639 & .644 \\
Chi-square & 726.469 & 729.940 \\
NFI & .751 & .750 \\
\hline
\end{tabular}

Table 7. Discriminant validity. Fornell-Larcker criterion.

\begin{tabular}{cccccc}
\hline & F1 & F2 & F3 & F4 & SPQF \\
\hline F1 & $(.769)$ & & & & \\
F2 & .360 & $(.816)$ & & & \\
F3 & -.161 & -.144 & $(.866)$ & & \\
F4 & .115 & .118 & -.351 & $(.894)$ & \\
SPQF & .191 & .402 & -.397 & .447 & 1.000 \\
\hline
\end{tabular}


Table 8. Reliability and construct validity.

\begin{tabular}{ccccc}
\hline & Cronbach's Alpha & Reliability coefficient rho_A & Composite reliability & Average variance extracted \\
\hline F1 & .943 & .952 & .949 & .592 \\
F2 & .875 & .884 & .909 & .667 \\
F3 & .673 & .709 & .857 & .751 \\
F4 & .748 & .751 & .888 & .798 \\
SPQF & 1.000 & 1.000 & 1.000 & 1.000 \\
\hline
\end{tabular}

\section{Reliability of the scales}

McMillan and Schumacher (2005) indicate that all research instruments must meet a series of requirements to achieve minimal scientific rigor. Reliability analysis allows to determine the sensitivity of the instrument. This instrument should provide accurate and consistent results in similar measurement conditions (Grau, 1995). Through the internal consistency the homogeneity of the measurement scales is checked, which indicates to what extent the different questions of a scale are interrelated. In this paper, the Cronbach's alpha coefficient is used to analyze the internal consistency of the items that make up the questionnaire.

The internal consistency of the scales used to measure the opinions of respondents about their expectations and the operation of the facilities was checked. Table 8 reports the SmartPLS outputs of Cronbach's alpha, rho_A (reliability coefficient) and a measure of composite reliability, which may be considered acceptable on a 0-1 scale.

Thus, aninstrument translated, updated and refined) is obtained to assess the quality of the golf courses in Andalusia using user feedback. The questionnaire obtains information about the characteristics of each client, related to course use habits, inquiring about their expectations and contrasts them with their opinions on the operation, attending to 22 key aspects. It is considered that comparisons between expectations and performance assessments can be essential to improve the quality of the service.

1. The questionnaire consists of 39 items divided into four subscales and one open question for comments.

2. The first dimension / scale is made up of 8 questions, the user can choose the option (s) that best suits their situation from among those presented in the use of the course.

3 . The second dimension / scale, consists of 6 questions on sociodemographic aspects such as gender, age, country of birth, location and country where they usually reside and know their handicap (assessment of the level of play of an amateur golf player, with respect to the number of strokes - generally above - that he makes in a course, with respect to the number of strokes stipulated by a professional player).

4. In the scale on the quality of the services of the golf course, 22 items are evaluated in the two columns of expectations and performance from a Likert scale of 5 points from "strongly disagree" (1) to "strongly agreement" (5).

5. The fourth scale contains three questions, two questions about maintenance, and a Likert scale of 10 points from "very dissatisfied" (1) to "very satisfied" (10) on Specific perceived quality of facilities (with the golf course).

6. It ends with one (1) open question for notes / comments (Annex 1).

\section{Conclusions}

A tool in English has been adapted to the Spanish language, and this one has been chosen because it is the most complete, since from the beginning of its creation it has taken into account the participation and opinion in the perception of the user.

It is very important to know the perceived quality of golf users since there is a very important golf tourism industry in Spain. The translated and adapted questionnaire, in addition, has incorporated some items, preserving, and improving the reliability of the instrument.

It is a good tool to know the perceived quality of the services provided by golf courses/clubs, and it was designed to develop a set of performance indicators that are accepted by the industry as useful, reliable, cost-effective, and relevant.

In accordance with these results, managers are encouraged to focus on guiding the staff functions. The users' age, gender and handicap variables are determinant items in the evaluation of their perception of golf courses. Therefore, the staff needs to be trained to develop their skills to giving an individual and specialized service to the users of these sport spaces. It is suggested, for better efficiency, to pay special care to the parking of the golf course and to keep clean the sport areas. 
In addition, it is necessary to generate new lines of research the perceived quality to customers have been living through lockdowns because of the Covid-19. How is affecting the pandemic to the relationship between the golf courses, the agents involved and to design security protocols that can determine an individual's decision to attend or not a golf course.

\section{Practical Implications}

Through the execution of the planned research tasks, the main objective of adapting the original questionnaire of Crilley et al. (2002) to the Spanish language. The contents from the version translated by professionals have been reviewed by a panel of expert judges. The questionnaire has been updated with the addition of four new items and has been successfully applied testing reliability and validity (Bolarinwa, 2015).

This research provides a questionnaire called Analysis of Perceived Quality of the Game of Golf (CAPG) to be applied in the field of management of golf courses. Although this tool has been designed to be applied in the management golf courses in Andalusia, its gene- ralization can be assessed for its application in other regions.

This tool has an important value for the managers of this field, since it provides relevant information that allows establishing user profiles for their best service, assessing the expectations of external customers as well as the level of perception of the quality of the operation of the facilities, and thereby detect deficiencies in the service and establish actions for the continuous improvement of the quality of the golf courses and the services they offer.

\section{Limitations and Future Studies}

This investigation is an adaptation of the English questionnaire into Spanish, and it is important to conduct to another Spanish regions and therefore, and to undertake transcultural studies in countries in Latin America that have Spanish as a mother tongue to make some comparisons in terms of cultural context. It is a relevant instrument because can help to managers to monitor and improve their performance through active, informed decision making. 


\section{ANNEX 1. CUESTIONARIO ANÁLISIS DE “CALIDAD PERCIBIDA EN EL JUEGO DEL GOLF (CAPG)}

Por favor ayúdenos a evaluar los servicios de los campos de golf rellenando este cuestionario. Ello no debe llevarle más de 7 minutos. Sus respuestas serán anónimas y confidenciales y reflejarán sus opiniones.

Se establecen 4 bloques de opinión:
1) Uso del campo de Golf
2) Características sociodemográficas
3) Opinión sobre la calidad de los servicios del campo de golf
4) Consideraciones especiales del campo

\section{1.- USO DEL CAMPO DE GOLF}

Por favor SEÑALE la respuesta más acorde

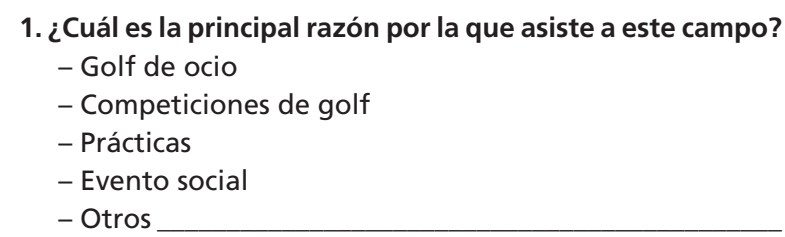

2. ¿Es usted socio de este campo de golf? - Sí

- No

3. ¿A qué distancia está el campo de golf de su casa?

$-5 \mathrm{~km}$ o menos

- Más de 5 a $10 \mathrm{~km}$

- Más de 10 a $40 \mathrm{~km}$

- Más de 40 km

4. Como media, ¿con qué frecuencia visita el campo?

- Ocasionalmente (solo períodos vacacionales)

$-<1$ al mes

-1 - 2 veces al mes

$-3-4$ veces al mes

$->4$ veces al mes

5. ¿Cuánto tiempo pasa en el campo?

$-<3$ horas

$-3-4$ horas

-4 - 5 horas

$->5$ horas
6. Normalmente, ¿a qué hora comienza a jugar?

- Antes de las 9:00h

$-9: 00 \mathrm{~h}-12: 00 \mathrm{~h}$

$-12: 00 \mathrm{~h}-15: 00 \mathrm{~h}$

- Después de las 15:00h

7. ¿Cuántos días de la semana juega habitualmente?

- Los días laborables

- Sábados

- Domingos

- Toda la semana

- Fines de semana completos

- Algún día laboral y algún día del fin de semana

- Periodos vacacionales

- Otros

8. ¿Cuándo empezó a jugar en este campo?

$-<1$ mes

-1 - 6 meses

-6 - 1 año

-1 - 2 años

-2 - 5 años

$->5$ años

\section{2.- CARACTERÍSTICAS SOCIODEMOGRÁFICAS}

1. Localidad donde reside habitualmente

2. País

3. Edad

4. Género

5. País de nacimiento

6. ¿Cuál es su handicap? 


\section{3.- OPINIÓN SOBRE LA CALIDAD DE LOS SERVICIOS DEL CAMPO DE GOLF}

A continuación, se recogen algunas frases.

Como cliente de este campo va a realizar la comparativa entre las expectativas de cómo espera que se esté gestionando el campo (A-expectativas) y cómo cree que realmente está funcionando el campo (B-Funcionamiento).

La evaluación es de 1 (en desacuerdo) a 5 (absolutamente de acuerdo).

POR FAVOR MARQUE "X" tanto en la casilla de expectativas (A) como en la de funcionamiento (B) con la valoración con la que esté más de acuerdo.

1 (en desacuerdo) - 5 (absolutamente de acuerdo)

1 (en desacuerdo) - 5 (absolutamente de acuerdo)

\begin{tabular}{|c|c|c|c|c|c|c|c|c|c|c|}
\hline \multicolumn{5}{|c|}{$\begin{array}{c}\text { A } \\
\text { EXPECTATIVAS }\end{array}$} & \multirow[t]{2}{*}{ PREGUNTA } & \multicolumn{5}{|c|}{$\begin{array}{c}\text { B } \\
\text { FUNCIONAMIENTO }\end{array}$} \\
\hline 1 & 2 & 3 & 4 & 5 & & 1 & 2 & 3 & 4 & 5 \\
\hline 1 & 2 & 3 & 4 & 5 & 2. El aparcamiento debe ser adecuado & 1 & 2 & 3 & 4 & 5 \\
\hline 1 & 2 & 3 & 4 & 5 & $\begin{array}{l}\text { 3. Las instalaciones integradas en el campo deben estar limpias y ordenadas } \\
\text { (tienda, sala) }\end{array}$ & 1 & 2 & 3 & 4 & 5 \\
\hline 1 & 2 & 3 & 4 & 5 & $\begin{array}{l}\text { 4. Debe facilitarse información sobre las normas del campo, la dirección, } \\
\text { etiqueta, horarios etc. }\end{array}$ & 1 & 2 & 3 & 4 & 5 \\
\hline 1 & 2 & 3 & 4 & 5 & 5. El campo debe ofrecer varias instalaciones de prácticas para los jugadores & 1 & 2 & 3 & 4 & 5 \\
\hline 1 & 2 & 3 & 4 & 5 & $\begin{array}{l}\text { 6. El campo debe ofrecer competiciones, instalaciones y programas que tengan } \\
\text { una buena relación calidad/precio }\end{array}$ & 1 & 2 & 3 & 4 & 5 \\
\hline 1 & 2 & 3 & 4 & 5 & 7. El campo debe ofrecer servicios de restauración (comida y bebida) & 1 & 2 & 3 & 4 & 5 \\
\hline 1 & 2 & 3 & 4 & 5 & 8. La tienda debe tener una amplia gama de equipos de golf y accesorios & 1 & 2 & 3 & 4 & 5 \\
\hline 1 & 2 & 3 & 4 & 5 & 9. El equipamiento de la tienda de golf debe ser de alta calidad (carros y palos) & 1 & 2 & 3 & 4 & 5 \\
\hline 1 & 2 & 3 & 4 & 5 & 10. Las normas del club y las reglas de etiqueta deben ser respetadas & 1 & 2 & 3 & 4 & 5 \\
\hline
\end{tabular}

\begin{tabular}{|c|c|c|c|c|c|c|c|c|c|c|}
\hline \multicolumn{5}{|c|}{$\begin{array}{c}\text { A } \\
\text { EXPECTATIVAS }\end{array}$} & PREGUNTA & \multicolumn{5}{|c|}{$\begin{array}{c}\text { B } \\
\text { FUNCIONAMIENTO }\end{array}$} \\
\hline 1 & 2 & 3 & 4 & 5 & $\begin{array}{l}\text { 11. El campo debe ser de alta calidad e incluir elementos apropiados (diseño, } \\
\text { paisaje, obstáculos y elementos del campo) }\end{array}$ & 1 & 2 & 3 & 4 & 5 \\
\hline 1 & 2 & 3 & 4 & 5 & $\begin{array}{l}\text { 12. Todas las áreas del campo deben estar bien mantenidas (tee de salida, green, } \\
\text { bunkers) }\end{array}$ & 1 & 2 & 3 & 4 & 5 \\
\hline 1 & 2 & 3 & 4 & 5 & 13. Debe haber suficientes fuentes de agua en el campo & 1 & 2 & 3 & 4 & 5 \\
\hline 1 & 2 & 3 & 4 & 5 & $\begin{array}{l}\text { 14. Debe haber en el campo un adecuado suministro de equipos de apoyo } \\
\text { (rastrillos, cubos de arena) }\end{array}$ & 1 & 2 & 3 & 4 & 5 \\
\hline 1 & 2 & 3 & 4 & 5 & 15. El personal del campo de golf debe ser experimentado y cualificado & 1 & 2 & 3 & 4 & 5 \\
\hline 1 & 2 & 3 & 4 & 5 & 16. El personal del campo de golf debe ser cordial & 1 & 2 & 3 & 4 & 5 \\
\hline 1 & 2 & 3 & 4 & 5 & $\begin{array}{l}\text { 17. El personal del campo de golf debe ser sensible a las necesidades de los } \\
\text { clientes }\end{array}$ & 1 & 2 & 3 & 4 & 5 \\
\hline 1 & 2 & 3 & 4 & 5 & 18. El personal del campo de golf debe ser presentable y fácilmente identificable & 1 & 2 & 3 & 4 & 5 \\
\hline 1 & 2 & 3 & 4 & 5 & 19. Tiene el club zona social & 1 & 2 & 3 & 4 & 5 \\
\hline 1 & 2 & 3 & 4 & 5 & 20. Esta el club preparado para personas de movilidad reducida & 1 & 2 & 3 & 4 & 5 \\
\hline 1 & 2 & 3 & 4 & 5 & $\begin{array}{l}\text { 21. La página web del campo ofrece información de TODOS los servicios que } \\
\text { presta }\end{array}$ & 1 & 2 & 3 & 4 & 5 \\
\hline 1 & 2 & 3 & 4 & 5 & 22. El estado de los greens SIEMPRE está en perfectas condiciones & 1 & 2 & 3 & 4 & 5 \\
\hline
\end{tabular}




\section{4.- CONSIDERACIONES ESPECIALES DEL CAMPO}

1. ¿La relación calidad-precio de la salida al campo es adecuada? Sí No

2. ¿Considera que existen áreas del campo descuidadas? (señale las que considere)

- Campo de prácticas

- Pitching green

- Putting green

- Calle

- Bunker

- Rough

- Green

3. Basado en toda su experiencia, por favor indique cómo siente que es la calidad percibida de forma específica, como cliente de este campo:

Muy Insatisfecho

Muy Satisfecho

\begin{tabular}{|l|l|l|l|l|l|l|l|l|l|l|}
\hline 0 & 1 & 2 & 3 & 4 & 5 & 6 & 7 & 8 & 9 & 10 \\
\hline
\end{tabular}

Observaciones, comentarios

Gracias por su colaboración 


\section{REFERENCES}

Aguirre Newman (2011). Estudio de mercado. Campos de golf en España. Feria Internacional del Golf, Noviembre, Madrid.

Alaminos, C., \& Castejón, J. L. (2006). Elaboración, análisis e interpretación de encuestas, cuestionarios y escalas de opinión. Editorial Marfil, S. A

Alonso-Dos-Santos M., \& Pérez-Campos C. (2015). Do emotions influence the intention of attending a sporting event? Differences by gender. Journal of Sports Economics \& Management, 5, 2-16. http:// sportsem.uv.es/j_sports_and_em/index.php/JSEM/article/view/38

Alonso-Serrano, J., \& Segado-Segado, F. (2015). Análisis de las herramientas de medición de percepción de la calidad en los servicios deportivos: Revisión de la literatura. Cultura, Ciencia y Deporte, 10(28), 67-76. http://dx.doi.org/10.12800/ccd.v10i28.516

Aymerich, F., \& Anabitarte, J. (2016). El Impacto Económico del Golf en España. http://www.rfegolf.es/ArtculosDocumento/Turismo\%20e\%20 impacto\%20econ\% C3\%B3mico/Turismo\%20e\%20impacto\%20econ\% C3\%B3mico\%20201 Accesed 23 March 2016.

AENOR (2008). Norma UNE: 188001. Campos de golf. Requisitos para la prestación del servicio. Madrid. https://www.aenor.com/normas-y-libros/buscador-de-normas/une?c=N0040701. Accessed 17 Mayo 2012.

AENOR (2011). Norma UNE: 188001. Campos de golf: requisitos para la prestación del servicio. www.aenor.es. Accessed 17 May 2012.

Barciela, F. (2017). La industria del golf sale del hoyo. La crisis y las nuevas regulaciones para el sector como las relativas al consumo de agua han propiciado la creación de empresas de servicios. https://elpais.com/economia/2017/11/30/actualidad/1512058937_849515.html. Accessed 17 November 2017.

Baumgartner, T. A. (2000). Estimating the stability reliability of a store. Measurement in Physical Education and exercise Science, 4(3), 175-178. https://doi.org/10.1207/S15327841Mpee0403_3

Benítez, J. (2013). Turismo cree que la subida del IVA del golf resulta "nociva" para el sector. Diario de Cádiz. http://www.diariodecadiz.es/ provincia/Turismo-IVA-resulta-nociva-sector_0_720828101.html. Accesed 31 July 2013.

Bolarinwa, O. (2015). Principles and Methods of validity and Reliability testing of questionnaires used in social and health sciences researchs. Nigerian postgraduate medical journal, 22(4), 195-201. https://doi. org/10.4103/1117-1936.173959

Brady, M. K., \& Cronin, J. J. (2001). Some new thoughts on conceptualizing perceived service quality: a hierarchical approach. Journal of Marketing, 65, 34-49. https://doi.org/10.1509/jmkg.65.3.34.18334

Brady, M., Knight, G., Cronin, J. J., Tomas, G., Hult, M., \& Keillor, B. (2005). Removing the contextual lens: a multinational, multi-setting comparison of service evaluation models. Journal of Retailing, 81, 215-230. https://doi.org/10.1016/j.jretai.2005.07.005

Cabero, A., \& Llorente, M. (2013). La aplicación del juicio de experto como técnica de evaluación de las tecnologías de la información y comunicación (TIC). Eduweb, 7(2), 11-22. http://servicio.bc.uc.edu. ve/educacion/eduweb/v7n2/art01.pdf. Accessed 2 sep 2020.

Calabuig-Moreno, F., \& Crespo, J. (2009). Uso método Delphi para la elaboración de una medida de calidad percibida de los espectadores de eventos deportivos. Retos. Nuevas Tendencias en la Educación Física, Deporte y Recreación, 15, 21-25. https://doi.org/10.47197/retos.v0i15.34993

Calabuig-Moreno, F., Burrillo, P., Crespo, J., Mundina, J. J., \& Gallardo, L. (2010). Satisfaction, quality and perceived value in spectators of athletics. Revista Internacional de Medicina y Ciencias de la Actividad Física y el Deporte, 10, 577-593. http://cdeporte.rediris.es/revista/ revista40/artsatisfaccion182.htm. Accessed 2 sep 2020.

Calabuig-Moreno F., Prado-Gascó V., Crespo-Hervás J., Núñez-Pomar J., \& Añó-Sanz V. (2015). Spectator emotions: effects on quality, satisfaction, value, and future intentions. Journal of Business Research, 68, 1445-1449. https://doi.org/10.1016/j.jbusres.2015.01.031

Calidad y Turismo (2012). Esquema de la norma UNE 188001:2008. http://www.calidadyturismo.es/dnn/Sectores/CamposdeGolfUNE 188001.aspx. Accessed 4 Mar 2012.

Carretero-Dios, H., \& Pérez, C. (2005). Normas para el desarrollo y revisión de estudios instrumentales. International Journal of Clinical and Health Psychology, 5(3), 521-551. http://www.aepc.es/ijchp/articulos_pdf/ijchp-158.pdf. Accessed 2 sep 2020.

Chelladurai, P., \& Chang, K. (2000). Targets and standards of quality in sport services. Sport Management Review, 3(1), 1-22. https://doi. org/10.1016/S1441-3523(00)70077-5

Clemes, M. D., Brush, G. J., \& Collins, M. J. (2011). Analysing the pro- fessional sport experience: a hierarchical approach. Sport Management Review, 14, 370-388. https://doi.org/10.1016/j.smr.2010.12.004

Crilley, G., Murray, D., \& Howat, G. (1999). Beyond the bottom line: Indicators for efficiency in public sports and leisure centres', in Blending a Nation, Conference Proceedings, Parks and Leisure-Australia 27-29 September, Park and Leisure Australia, Adelaide (CD-ROM)

Crilley, G., Murray, D., Howat, G., \& Milne, I. (1997). The cost-quality relationship in Australian public sports and leisure centres: Conventional wisdom revisited', in Rowe, D. and Brown, P. (Eds) ANZALS Conference Proceedings, Australian and New Zealand Association for Leisure Studies, Newcastle, Australia, pp. 42-47.

Crilley, G., Murray, D., Howat, G., March, H., \& Adamson, D. (2002). Measuring Performance in operational management and customer service quality. A survey of financial and non-financial metrics from the Australia golf Industry. Journal of Leisure Property, 2(4), 369-371. shorturl.at/svBF5. Accessed 2 sep 2015.

Crespo-Hervás, J., Calabuig-Moreno, F., Prado-Gascó, V., Añó-Sanz, V., \& Núñez-Pomar, J. (2019). The role of passion in the quality-valuesatisfaction-intentions chain: linear models and the QCA approach for athletes. Economic Research-Ekonomska Istraživanja, 32, 352-369. https://doi.org/10.1080/1331677X.2018.1553683

Cronin, J. J., Brady, M. K., \& Hult, G. T. M. (2000). Assessing the effects of quality, value, and customer satisfaction on consumer behavioural intentions in service environments. Journal of Retailing, 76, 193-218. https://doi.org/10.1016/S0022-4359(00)00028-2

Conroy, D., \& Metzler, J. (2003). Factorial Invariance and Latent Mean Stability of Performance Failure Appraisals. Structual equation modeling, 10(3), 401-422. https://doi.org/ 10.1207/S15328007 SEM1003 4Daouk, L., McDowall, A., \& Rust, J. (2006). A multimethod approach to cross-cultural test adaptation: A focus on qualitative methods. http://www.intestcom.org/ Conferences/2006+conference. php. Accessed 21 July 2018.

Daouk, L., McDowall, A., \& Rust, J. (2006). A multi-method approach to crosscultural test adaptation: A focus on qualitative methods. http://www.intestcom.org/ Conferences/2006+conference.php. Accessed 21 July 2018.

Decreto 309/2010, de 15 de junio, por el que se modifica el Decreto $43 / 2008$, de 12 de febrero, regulador de las condiciones de implantación y funcionamiento de campos de golf en Andalucía.

Diario de Sevilla. (14 de marzo, 2015). Andalucía se sitúa como destino de golf entre operadores de EEUU. https://www.diariodesevilla.es/economia/Andalucia-situa-destino-operadores-EEUU_0 898110436. html\#!. Accessed 17 Mar 2015.

Díaz, A., Betancourt, M. A., \& Molinet, T. (2013). El sistema de revenue management como técnica de gestión de las capacidades hoteleras. Gran Tour: Revista de Investigaciones Turísticas, 7, 23-38. https://cutt. ly/PkJYhdQ. Accessed 11 Mar 2019.

Dunn, J. G., Bouffard, M., \& Rogers, W. T. (1999). Assessing item contentrelevance in sport psychology scale-construction research: issues and recommendations. Measurement in Physical Education \& Exercise Science, 3(1), 15-22. https://doi.org/10.1207/s15327841mpee 0301_2

Escobar-Pérez, J., \& Cuervo-Martínez, A. (2008). Validez de contenido $y$ juicio de expertos: una aproximación a su utilización. En Avances en Medición, 6, 27-36. http://www.humanas.unal.edu.co/psicometria/ files/7113/8574/5708/Articulo3_Juicio_de_expertos_27-36.pdf. Accessed 11 Mar 2019.

Gálvez-Ruiz, P., \& Morales-Sánchez, V. (2015). Desarrollo y validación del cuestionario para la evaluación de la calidad percibida en servicios deportivos. Cultura, Ciencia y Deporte, 10(28), 55-66. http://dx.doi. org/10.12800/ccd.v10i28.515

García-Tascón, M. (2009). Análisis de la percepción de la satisfacción del clima laboral en las organizaciones deportivas municipales de Castilla-La Mancha (Doctoral dissertation, Universidad de Castilla-La Mancha). http://igoid.uclm.es//Tesis/Tesis_MartaGarciaTascon.pdf. Accessed 11 Feb 2019.

Grau, G. (1995). Metodología para la validación de cuestionarios. Medifam, 5(6), 351-359.

González, J. I., \& Suárez, O. (2011). Diagnóstico del marketing del producto Golf en la instalación Varadero Golf Club Cuba. http://www.gestiopolis. com/marketing-2/diagnostico-marketing-producto-golf-instalacionvaradero-golf-club-cuba.htm. Accessed 11 Feb 2019.

Grimaldi Puyana, M., Sánchez Oliver, A. J., Macías Plá, R., \& Álvarez García, J. (2018). Perfil, evolución y características de las organizaciones de 
gestión de campos de golf en España. Revista Espacios, 39(33), 30-34. https://www.revistaespacios.com/a18v39n33/18393330.html. Accessed 11 Feb 2019

Hambleton, R. K. (2006). Issues, designs and technical guidelines for adapting tests into multiple languages and cultures. En R.K. Hambleton, P.F. Merenda y C.D. Spielberger (Eds.): Adapting educational and psychological tests for crosscultural assessment, (3-38). Mahwah, NJ: Lawrence Erlbaum Associates.

Hightower, R., Brady, M. K., \& Baker, T. L. (2002). Investigating the role of the physical environment in hedonic service consumption: an exploratory study of sporting events. Journal of Business Research, 55, 697-707. https://doi.org/10.1016/S0148-2963(00)00211-3

Instituto para la calidad turística española (2011). El Campo de la Real Federación Española de Golf, certificado con la "Q" de Calidad Turística. https://calidadturisticahoy.es/ESP/m/36/520/Reconocimientos/ Listados/El-Campo-de-la-Real-Federacion-Espanola-de-Golf--certificado-con-la-Q-de-Calidad-Turisti. Accessed 22 sep 2018.

Kim, W., \& Walker, M. (2012). Measuring the social impacts associated with Super Bowl XLIII: Preliminary development of a psychic income scale. Sport Management Review, 15, 91-108. https://doi. org/10.1016/j.smr.2011.05.007

Ko, Y., Kim, Y., \& Lee, J. (2010). The role of involvement and identification on event quality perceptions and satisfaction. A case of US Taekwondo Open. Asia Pacific Journal of Marketing and Logistics, 22, 25-39. https://doi.org/10.1108/13555851011013137

KPGM (2016). Golf Participation Report for Europe 2016. http:// golfbenchmark.com/article/golf_participation_report_for_europe_2016. Accessed 7 jul 2019.

Lambrect, K. W., Kaefer, F., \& Ramenofsky, S. D. (2009). Sportscape factors influencing spectator attendance and satisfaction at professional golf association tournament. Sport Marketing Quarterly, 8, 165-172. http:// fitpublishing.com/content/sportscape-factors-influencing-spectatorattendance-and-satisfaction-professional-golf. Accessed 22 sep 2020.

Magaz-González, A. M., Sahelices-Pinto, C., Mendaña-Cuervo, C. \& García-Tascón, M. (2020). Overall Quality of Sporting Events and Emotions as Predictors of Future Intentions of Duathlon Participants. Frontiers in Psychology, 11, 1432-1445. https://doi. org/10.3389/fpsyg.2020.01432.

Martín Arribas, M. C. (2004). Diseño y validación de cuestionarios. Ma tronas profesión, 5(17), 23-29. http://www.enferpro.com/documentos/validacion cuestionarios.pdf. Accessed 22 sep 2020

Martínez-García, J. A., \& Martínez-Caro, L. (2010). Rethinking perceived service quality: an alternative to hierarchical and multidimensional models. Total Quality Management \& Business Excellence, 21 93-118. https://doi.org/10.1080/14783360903492694

McDougall, G. H., \& Levesque, T. (2000). Customer satisfaction with services: putting perceived value into the equation. Journal of Services Marketing, 14, 392-410. https://doi.org/10.1108/08876040010340937

McMillan, J., \& Schumacher, S. (2005). Investigación educativa. Pearson Educación.

Montesinos-Saura E., Vegara-Ferri J. M., Morales-Baños V., López-Gullón M. J., López-Sánchez G. F., \& Angosto-Sánchez S. (2018). Perceived quality, perceived value, satisfaction and future intentions in participants in swimming crossings. Journal of Physical Education and Sport, 18, 1316-1322. https://doi.org/10.7752/jpes.2018.s3195

Murray, D., \& Howat, G. (2002). The relationships among service quality, value, satisfaction, and future intentions of customers at an Australian sports and leisure centre. Sport Management Review, 5(1) 25-43. https://doi.org/10.1016/S1441-3523(02)70060-0

Parasuraman, A., Zeithaml, V. A., \& Berry, L. L. (1985). A conceptual model of service quality and its implications for future research. Journal of Marketing, 49, 41-50.https://doi.org/10.1177/002224298504900403

Parasuraman, A., Zeithaml, V. A., \& Berry, L. L. (1988). SERVQUAL: multiple-item scale for measuring consumer perceptions of service quality. Journal of Retailing, 64, 12-40. https://n9.cl/grs6b. Accessed 20 sep 2018

Pérez-Campos, C. (2010). Análisis de la Calidad de Servicio en los Eventos Deportivos: Calidad Percibida y Satisfacción de los Espectadores y de Lo Deportistas. Ph.D. tesis, Universitat de Valéncia, Servei de Publicacions, Valencia. https://doi.org/10.10803/52093

Pérez, C., Fernández, J. S., \& Rojas, A. (1998). Investigar mediante encuestas: Fundamentos teóricos y aspectos prácticos. Síntesis.

Pérez, A. (2001). Modelo y sistema de evaluación de la Empresa Cubana de Alto Desempeño. En Seminario Iberoamericano para la Ciencia y la Innovación. La Habana. Cuba.
Pincay Quimiz, V., \& Romero Maquillón, M. G. (2015). Diseño implementación de un sistema de control interno para optimizar el uso de los recursos humanos, materiales y financieros en la urbanizacion Mocoli golf club de la ciudad de Guayaquil. Tesis doctoral. Facultad de ciencias administrativas. Universidad de Guayaquil.

Real Federación Andaluza de Golf -RFAG- (2020a). Datos estadísticos. Recuento de campos por autonomías. https://n9.cl/30z3. Accessed on 15 August 2020.

Real Federación Andaluza de Golf -RFAG- (2020b). Guía oficial de campos de golf 2020. http://www.rfegolf.es/PaginasServicios/DetallesDescarga.aspx?DId=1147. Accessed on 15 August 2020.

Real Federación Española de GOLF -RFAG- (2020). Evolución de licencias desde 1967. http://www.rfegolf.es/ArtculosDocumento/LICENCIAS/ evolucionlicencias.pdf. Accessed 11 Feb 2019.

Ringle, C. M., Wende, S., \& Becker, J. M. (2015). SmartPLS 3. Boenningstedt: SmartPLS GmbH, http://www.smartpls.com.

Ruiz, A. (2014). La operacionalización de elementos teóricos al proceso de medida, col. Omado, Barcelona: Universitat de Barcelona. http://hdl. handle.net/2445/53152. Accessed 20 Feb 2019

Serrano-Gómez, V., Rial-Boubeta, A., García-García, O., \& HernándezMendo, A. (2010). La evaluación de la calidad percibida del servicio como elemento clave para la gestión de los clubs de golf en España. Apunts Educación Física y Deportes, 102, 95-105. https://n9.cl/bgcj. Accessed on 15 August 2016.

Serrano-Gómez, V., Rial Boubeta, A., García-García, O., \& Gambau i Pinasa, V. (2013). QGOLF-9: Escala para la evaluación de la calidad percibida en los clubes de golf. Revista de Psicología del Deporte, 22(1), 111-121. https://n9.cl/nv6e7. Accessed on 15 August 2016.

Shonk, D. J., \& Chelladurai, P. (2008). Service quality, satisfaction, and intent to return in event sport tourism. Journal of Sport Management, 22, 587-602. https://doi.org/10.1123/jsm.22.5.587

Theodorakis, N., Kambitsis, C., Laios, A., \& Koustelios, A. (2001). Relationship between measures of service quality and satisfaction of spectators in professional sports. Journal of Service Theory and Practice, 11 431-438. https://doi.org/10.1108/09604520110410638

Theodorakis, N., Kostas, A., Tsigilis, N., \& Karvounis, S. (2013). Predicting spectators' behavioural intentions in professional football: the role of satisfaction and service quality. Sport Management Review, 16, 85-96. https://doi.org/10.1016/j.smr.2012.05.004

Thomas, J. R., \& Nelson, J. K. (2007). Métodos de investigación en actividad física. Les Guixeres, Editorial Paidotribo.

Trigueros, R., Magaz-González, A. M., García-Tascón, M., Alias, A., \& Aguilar-Parra, J. M. (2020). Validation and Adaptation of the Academic-Resilience Scale in the Spanish Context. International Journal of Environmental Research and Public Health, 17(11), 3779-3790. https:// doi.org/10.3390/ijerph17113779

Tsitskari, E., Tsiotras, D., \& Tsiotras, G. (2006). Measuring service quality in sport services. Total Quality Management \& Business Excellence, 17(5), 623-631. https://doi.org/10.1080/14783360600588190

Vacher, P., Nicolas, M., Martinent, G., \& Mourot, L. (2017). Changes of swimmers' emotional states during the preparation of national championship: do recovery-stress states matter? Frontiers in Psychology, 8, 1043. https://doi.org/10.3389/fpsyg.2017.01043

Venerandi, M. (2012). Propuesta de un modelo gráfico de análisis aplicado en las organizaciones deportivas municipales de Castilla-La Mancha. (Doctoral dissertation, Universidad de Castilla-La Mancha. http:// igoid.uclm.es/Tesis/Tesis_MarceloVenerandiOjeda.pdf. Accessed 11 Feb 2019.

Visitacostadelsol.com. (2018). Turismo y Planificación Costa del sol. http://www.visitacostadelsol.com. Accesed 11 Jun 2019.

Wieserma, L. D. (2001). Conceptualization and development of the sources of enjoyment in youth sport questionnaire. Measurement in Physical Education and Exercise Science, 5(3), 153-157. https://doi. org/10.1207/S15327841MPEE0503_3

Zhu, W., Ennis, C. D., \& Chen, A. (1998). Many-faceted rasch modeling expert judgment in test development. Measurement in Physical Education and Exercise Science, 2(1), 21-39. https://doi.org/10.1207/ s15327841mpee0201_2

Zarco-Pérez, P., Gallardo, A., García-Unanue, J., Plaza-Carmona, M., Felipe, J. F., García-Tascón, M. Burillo, P \& Gallardo, L. (2012). Análisis de la accesibilidad en los campos de golf de la Región de Murcia. Cultura, Ciencia y Deporte, 7(20), 89-94. http://dx.doi.org/10.12800/ccd.v7i20.54

Zeithaml, V., Berry, L., \& Parasuraman, A. (1996). The behavioral consequences of service quality. Journal of Marketing, 60, 31-46. https:// doi.org/10.2307/1251929 